\title{
The Vermiform Appendix in Relation to Pelvic Inflammation, with an Analysis of Ten Cases.*
}

\author{
By Arnold W. W. LeA, M.D., B.S. (Lond.), F.R.C.S. (Eng.), \\ Lecturer on Obstetrics and Diseases of Women, Manchester \\ University; Surgeon, Northern Hospital for Women; and \\ Assistant Surgeon, St. Mary's Hospitals, Manchester.
}

THE vermiform appendix is so frequently a pelvic organ that it merits the attention of all gynæcologists. During the last few years its importance in relation to disease of the pelvic viscera has been generally recognized, and the advisability of removal of the appendix when the abdomen is opened for pelvic lesions has been much discussed.

The recent monograph on "Diseases of the Appendix," by Howard A. Kelly, is a contribution of the greatest value, and contains very complete references to the literature of the subject.

I purpose briefly to review the anatomical and pathological relations of the appendix to the pelvic viscera, and to record ten cases in which lesions of the appendix were found in association with pelvic inflammation.

\section{Anatomy of the Aprendix Vermiformis.}

The point of origin of the appendix from the cecum is fairly constant, but its length, the direction of its axis, and its relations to the peritoneum show wide variations. The appendix frequently occupies the pelvis. Thus Hawkins ${ }^{1}$ found the appendix in the true pelvis in 19 per cent. of autopsies. Robinson, ${ }^{2}$ in 128 examinations, found the appendix to be pelvic in 48 per cent. of females and in 37 per cent. of males. Lockwood, ${ }^{3}$ in 109 consecutive operations, observed the appendix to be pelvic in 15, and in a later series of 200 cases the appendix was pelvic in 37 . Kelly ${ }^{4}$ estimates that in 25 per cent. of women the appendix is dependent in the pelvis.

Usually, the appendix is situated behind the ovary and tube, and it may reach the floor of the pelvis. Rarely it lies in front of the broad ligament in the utero-vesical pouch.

A lymphatic and vascular connection between the ovary and the - Amplified from a paper read before the North of England Obst. and Gyn. Soc.,
March 15th, 1906. 
appendix has been traced by several observers. Thus Clado, ${ }^{5}$ Durand, ${ }^{6}$ and others have described a definite fold of peritoneum passing upwards from the infundibulo-pelvic ligament to the mesoappendix, and have called this the "appendiculo-ovarian" ligament. They believed that in this way a direct lympathic path is established providing a ready means for the propagation of infection. Recent researches by Craig, ${ }^{7}$ Poirier, ${ }^{8}$ Kelly, and others have shown that this ligament is only occasionally present, and is merely a peritoneal fold passing behind the meso-appendix. Morphologically it corresponds to the mesorchium, and indicates the line of descent of the ovary from the Wolffian body. All attempts by injection of the vascular and lymphatic systems have failed to demonstrate any direct connection between the appendix and the ovary.

It may, I believe, be definitely stated that the association of the appendix with disease of the pelvic organs is entirely due to its topographical relations to the pelvic viscera.

Frequency of Corncident Disease of the Appendix and the Pelvic Organs.

This has been variously estimated, much depending upon the exact definition of the changes in the appendix which are to be regarded as morbid. Dührssen ${ }^{9}$ found the appendix involved in 3 per cent. of laparotomies for pelvic disease. Amann, in 280 abdominal sections, observed 17 cases of disease of the appendix. Hermes, ${ }^{10}$ in a series of 75 consecutive operations, found abnormal changes in the appendix in no less than 53 per cent. The figures given by some American operators are remarkable. Dr. J. G. Clark, ${ }^{11}$ of the Johns Hopkins University, removed the appendix as a routine procedure in 120 consecutive cases of abdominal section. The appendix was carefully examined in each case. In 25 only was it absolutely normal. Peri-appendicitis was present in 39 , various types of chronic appendicitis in 47 , and in one instance primary carcinoma was discovered. Peterson, ${ }^{12}$ who also advocates removal of the appendix as a part of all gynæcological abdominal operations, observed the condition of the appendix in 200 consecutive cases. No case was included in which the symptoms pointed primarily to the appendix. The appendix was examined microscopically in every instance. Forty-seven per cent. showed histological lesions, and the appendix was adherent in 18.5 per cent. He states that in nearly half the patients with chronic disease of the uterine appendages there is a morbid condition of the vermiform appendix, and since it is impossible to determine by external appearances whether the appendix 
is diseased or not, he concludes that it should be removed if no direct contra-indication exists. Kelly, in 240 cases of removal of the appendix, found appendicitis associated with inflammation of the pelvic organs in 64 cases. In seven instances this was associated with tubercular disease of the uterine appendages.

In a valuable paper Hunter Robb ${ }^{13}$ records his experience of the condition of the appendix in a series of 370 abdominal operations. In each instance the appendix was removed and microscopically examined. In 47 cases, i.e., 11.5 per cent., inflammatory changes were found in the appendix. In 148 cases of inflammatory disease of the tubes and ovaries, appendicitis was found in 25 , or 16.8 per cent.; in 64 cases of purulent disease of the tubes, appendicitis was present in 11, or 17 per cent. In 15 cases of cystic tumours, appendicitis existed in 4 , and in 18 operations for uterine myoma the appendix showed inflammatory changes in 3 cases. Careful examination of these appendices revealed, however, that lesions, apart from those produced by inflammation, were very frequent, so that only in 103 instances was the appendix held to be quite normal. Thus in 88, hypertrophy of the subperitoneal covering or of the mucosa existed. The lumen was occluded in 36 , dilated in 16 , and contained concretions in 12 .

From these figures it is obvious that morbid conditions of the appendix must exist in many apparently healthy people. Ribbert, ${ }^{14}$ in a series of 400 autopsies, found partial occlusion of the appendix in 99 , i.e., in 25 per cent., and obliteration of the lumen increases in frequency with advancing age. Sometimes this may be the result of inflammation, but it is probable that it is often an atrophic process. Fæcal concretions are probably present in at least 10 per cent. of individuals, and their existence must be a source of danger. The explanation of these facts seems to lie in the rudimentary condition of the appendix in the human race. Possibly it is destined ultimately to disappear; meantime, it is peculiarly liable to retrogressive changes.

Removal of the appendix in the absence of obvious disease or adhesions to viscera has not hitherto been the practice of English surgeons. Hence it follows that if the figures quoted above are even approximately true, morbid conditions of the appendix must often exist without producing any symptoms, or a number of our patients would not be completely relieved after operations on the pelvic organs. It is indeed probable that imperfect post-operative results are sometimes due to unrecognized lesions of the appendix, and there is also 
some evidence that disease of the appendix may follow pelvic operations.

I am not acquainted with any extensive series of detailed observations on the after histories of patients operated upon for pelvic disease, but the recent discussion at the Royal Medico-Chirurgical Society is valuable as giving the experience of general surgeons of results after removal of the appendix. Sir Frederick Treves, ${ }^{15}$ in his paper, records the after histories of 1,000 cases of appendectomy. Forty-five of these were incompletely relieved, and in nine instances this was due to co-existing disease of the right ovary, overlooked at the time of operation. Sir Frederick Treves, after stating that he was often unable to distinguish chronic disease of the right ovary from appendicitis, advised that the right ovary should be systematically examined when the appendix is removed. Mr. Lockwood, in his series of 200 cases of operation for appendicitis observed six instances of inflammatory disease of the right uterine appendages first recognized at the time of operation.

The association of lesions of the appendix with pelvic disease may arise in three ways :-

1. Appendicitis may be the primary lesion.

2. The appendix may be involved as a secondary result of tuboovarian disease or of a new growth in the pelvis.

3. The two affections may exist independently.

\section{Primary Pelvic Appendicrtis.}

Acute pelvic inflammation often terminating in abscess, is not uncommon as the result of acute appendicitis. Thus Rotter, ${ }^{16}$ in a series of 132 cases of suppurative appendicitis, observed 40 cases in which the pus filled the pouch of Douglas and in 21 of these it was limited to the pelvis. In these cases it is often difficult to determine the primary source of the infection, for the symptoms closely resemble those produced by acute peritonitis from infection of the uterus and tubes. The history of the illness, the absence of any of the usual causes of pelvic inflammation, and the limitation of the swelling to the right side may often enable a diagnosis to be made; but in very acute cases with diffuse peritonitis it is often not possible to differentiate between appendicitis and infective salpingitis.

In rare instances acute pelvic appendicitis may directly infect the uterine appendages, producing a pyosalpinx or ovarian abscess. An example of this was recently recorded by Bland-Sutton, ${ }^{17}$ in which 
the acutely inflamed appendix ruptured into the abdominal ostium of the adherent Fallopian tube.

Pelvic abscess the result of acute appendicitis may attain a large size, and closely simulate an ovarian cyst which has undergone acute torsion or become infected. The swelling is usually central, and may reach the umbilicus. The encysted exudation either lies in front of the uterus, which is then pushed to the floor of the pelvis, or fills up Douglas's pouch. Evacuation of the pus through the abdomen or by posterior vaginal section is usually followed by complete recovery. Vaginal drainage is of especial value in these cases, and may be carried out even in children and young adults. ${ }^{18}$ In some instances adhesions remain around the uterus and its appendages, causing occlusion of the Fallopian tubes and permanent sterility.

Chronic pelvic appendicitis may develop without the formation of abscess. The fibrinous exudation is either completely absorbed or dense adhesions form around the uterus and its appendages. It is possible that these adhesions may remain as the only result of healed appendicitis, and be a cause of uterine displacements. Kelly states that in five out of eleven cases in which he found disease of the appendix associated with retroflexion, the uterus was bound down by adhesions, the Fallopian tubes being quite healthy; and he regards the appendix as being the primary cause of the perimetritis. The close anatomical relations between a pelvic appendix and the right broad ligament may lead to direct infection of the tube and ovary, or to the development of adhesions. The existence of a unilateral tubo-ovarian mass without evidence of uterine infection strongly suggests the appendix as the seat of disease. In young women the possibility of tubercular infection of the uterine appendages must always be considered. The appendix is infected with tubercle in many cases of tubercular salpingitis, but usually as a part of the general peritoneal infection.

\section{Changes in the Appendix Secondary to Tubo-Ovarian Disease.}

Inflammatory affections of the uterine adnexa are frequently associated with lesions of the appendix, and usually the primary infection is of pelvic origin. The appendix in at least 25 per cent. of women lies in close relation to the right Fallopian tube and ovary. If these are enlarged or inflamed the appendix readily becomes adherent. If the adhesions are slight and velamentous the appendix may remain healthy; more often secondary changes ensue either by interference with its nutrition by traction or kinking, or by direct bacterial invasion from the tube and ovary. 
The adherent appendix usually produces no characteristic symptoms. Peterson analysed the symptoms in his cases. He states that pain, possibly of appendical origin, existed in 45 per cent. of patients in whom the appendix was found diseased, but similar pain was present in 33 per cent. of patients in whom the appendix was shown to be healthy. It is practically impossible to diagnose an adherent appendix in association with tubo-ovarian inflammation.

I have arranged in tabular form all the examples of disease of the appendix associated with chronic tubo-ovarian disease which $\mathrm{I}$ have observed--eight in number. A study of these cases shows that the appendix was the primary source of infection in two instances (Nos. 1 and 5). In both the appendix contained pus, and the patient had suffered from recurrent attacks of pelvic peritonitis. In three cases (Nos. 2, 3 and 4) the appendix was involved as a secondary result of tubo-ovarian disease. In one case (No. 8) the source of infection cannot be certainly stated. In two cases (Nos. 6 and 7) lesions of the appendix were found in association with prolapsed and enlarged ovaries, and apparently arising independently of the pelvic affection.

The differential diagnosis between chronic appendicitis associated with acute attacks of localized peritonitis and tubo-ovarian disease on the right side is often difficult. In both, exacerbations of pelvic pain with pyrexia are liable to occur. The pain may be precisely similar, although usually the appendicular sensitive area is higher up, at or near McBurney's point. In chronic appendicitis there is a distinct tendency for the attacks of pain to develop at the menstrual periods. MacLaren ${ }^{19}$ has drawn attention to this feature, and has suggested that attacks of appendicular colic may be mistaken for spasmodic dysmenorrhœa. There is evidence that a chronic form of appendicitis exists apart from the acute recurrent type which is generally recognized, and this may be a cause of right-sided pelvic pain in women apart from lesions of the ovary or tube. This condition cannot be recognized by physical examination as the appendix may have undergone comparatively slight changes. This pain is worse at the menstrual periods, and is often regarded as "ovarian" in origin. Possibly in some cases the right ovary has been removed for "sclero-cystic" disease when the pain has really been due to the appendix.

The development of a pelvic inflammatory swelling in an unmarried girl or woman in whom gonorrhœeal or septic infection can be excluded, suggests an appendical origin, especially if the swelling is limited to the right side. Tubercular salpingitis may, 
however, present very similar clinical features, although here the affection is usually bilateral.

Ovarian Tumours and the Appendix.

The appendix is often adherent to ovarian tumours, especially if these have undergone torsion or become infected. Kelly observed an adherent appendix in 19 out of 300 operations for ovarian cystoma. Peterson states that in 17 out of 23 cases of ovarian tumour he found inflammatory changes in the appendix, but in only three instances was the appendix adherent to the cyst wall. Usually these adhesions are of little importance, but occasionally the appendix may infect the contents of an ovarian cyst. This is usually preceded by acute inflammation of the appendix. I have observed one instance of suppurating ovarian cyst in which the appendix was firmly incorporated in the cyst wall. Careful examination after removal did not reveal any pus in the appendix; hence the cause of the infection remains doubtful.

Acute torsion of an ovarian cyst may closely simulate appendicitis unless the case has been carefully observed from the first onset of the symptoms. The localized purulent peritonitis resulting from perforative appendicitis may form a definite tumour in front of or behind the uterus, with physical signs indistinguishable from those produced by an ovarian cyst which has become generally adherent.

\section{Tubal Pregnancy and the Appendix.}

Adhesion of the appendix to a tubal gestation sac is not uncommon. I have observed this in two cases (Nos. 9 and 10). The appendix was simply adherent, and was removed as a precautionary measure. Kelly records the appendix as being adherent in 10 per cent. of the cases operated upon by him. The appendix may possibly infect the gestation sac or a hæmatocele, and several examples of this have been recorded. The chief interest attaching to this subject lies in the diagnosis. Acute perforative appendicitis may simulate ruptured tubal pregnancy. Several instances have also been observed in which both affections were present at the same time.

Tubal pregnancy may exist without any evidence of menstrual disturbance or any signs of pregnancy, and the symptoms may be indistinguishable from acute appendicitis. Lapthorn Smith ${ }^{20}$ has recently recorded a case illustrative of these difficulties. The patient had missed two periods and was suffering from uterine hæmorrhage, associated with pyrexia and severe pelvic pain on the right side. A sausage-shaped swelling was felt in the posterior 
cul-de-sac, and a mass was also present in the right iliac region. On exploring the abdomen the appendix, almost perforated and gangrenous, was found embedded in adhesions at the floor of the pelvis. It was adherent to a coil of small intestine. This was much thickened, and had been felt in Douglas's pouch before operation resembling the pregnant Fallopian tube. The clinical symptoms and physical signs produced by an infected hæmatocele may be indistinguishable from those of suppurative appendicitis. Döderlein and Krönig point out that in these doubtful cases only vaginal drainage should be adopted.

\section{Appendicitis following Pelvic Operations.}

If abdominal or pelvic pain continues after operation on the uterus or its appendages the possibility of the appendix being at fault must be borne in mind, even if it was apparently healthy at the time of the operation. There is a distinct liability for lesions of the appendix to arise after pelvic operations. Exudation about the pedicle and subsequent adhesions may involve the appendix, or it may become adherent to raw surfaces about the brim or in the cavity of the pelvis. This is especially liable to occur if the appendix is "pelvic" in position.

I have observed four cases in which the appendix was removed after operations on the pelvic organs had failed to cure, and in each instance complete relief was afforded. In none of these patients had the symptoms prior to operation suggested that the appendix was at fault:-

CaSE I. An unmarried lady, æt. 39, had suffered for five years from chronic pelvic peritonitis. The general health was good. The usual causes of pelvic inflammation were absent. The uterus was retroverted and fixed. The appendages on both sides were enlarged and adherent. Abdominal section revealed omental and intestinal adhesions to the uterus and its appendages. On separating these the left tube and ovary showed chronic adhesive salpingo-oöphoritis. The right ovary was equal in size to a small orange, adherent to the Fallopian tube and the back of the uterus. It contained a hæmatoma, involving its entire structure. Both tubes and both ovaries were removed. The patient was much relieved, but did not entirely lose the pain on the right side. This gradually became worse, preventing her from walking. Twelve months later I again saw the patient. I concluded that the pain was due to the vermiform appendix, and advised its removal. I found the appendix bound down by adhesions to the brim of the pelvis, 
thickened and partially occluded. Since its removal the patient has been quite well. It is quite possible that in this instance the appendix was the primary cause of the pelvic peritonitis, and it ought to have been removed at the first operation.

CASE Ir. In 1903 I performed total abdominal hysterectomy on a patient, at. 42 , for myomata complicating pregnancy. She made a good recovery, but six months later began to complain of dragging pain in the right iliac region. As both ovaries had been removed I concluded that this pain was appendical in origin. Some months later, as the patient gradually became worse, I removed the appendix. It was lying at the pelvic brim, and showed peri-appendicitis with adhesions to the pelvic peritoneum. The patient was completely relieved, and has since remained well.

Case III. A patient, æt. 29, was seen in 1902 suffering from double tubo-ovarian disease of gonorrhoal origin. Abdominal section was performed. The appendages on both sides were removed. On the right side a pyosalpinx was present, on the left adhesive salpingooöphoritis. The patient made a good recovery. Some months later she began to suffer from constant dragging pain in the right iliac region. After waiting for a time, as the pain became aggravated, I removed the appendix. It was adherent at the pelvic brim and along the posterior wall of the cæcum. The pain was completely relieved, and the patient has remained well.

CASE Iv. Patient, æt. 42. Vaginal hysterectomy was performed for multiple myomata of the uterus. Recovery was uneventful, the temperature being normal throughout. Six months later she began to complain of severe dragging pain in the right iliac region, rendering her unable to walk or exert herself. As she became gradually worse the abdomen was explored by incision in the right linea semilunaris. The vermiform appendix was adherent, along with the omentum, to the cicatrix of the vaginal roof. The appendix was removed, and the omentum separated. This gave complete relief to the symptoms.

These cases clearly show that the possibility of lesions developing in the appendix after pelvic operations is by no means remote, and this is a factor to be weighed in deciding whether or not to remove the appendix as a part of these operations. It is very easy to overlook morbid conditions of the appendix unless the organ is carefully examined, and it is certain that some failures after pelvic operations are the result of disease of the appendix co-existent with but entirely independent of the pelvic lesions. It is to be noted also 
that the pain of chronic appendicitis may be indistinguishable from ovarian pain, and that it is almost always aggravated by the congestion occurring at the menstrual periods. A careful study of the history of the illness will often afford great help, but if any doubt exists the appendix must be thoroughly examined at the time of operation.

Although it is not possible to fix the precise frequency of morbid conditions of the appendix in apparently healthy women, or in women suffering from pelvic disease, it is abundantly demonstrated that it is wise to examine the appendix as a part of every abdominal operation, and especially in all cases of right-sided abdominal pain. The practice of removing the appendix in every case, even if apparently normal, has much to commend it. Kelly obtained the opinion of 73 surgeons in different parts of the United States on this point. Two-thirds of the replies were against removal of the normal appendix. If, however, the appendix is adherent there is a general agreement that it should be removed.

During the last three years I have examined the appendix in almost every case of abdominal section for pelvic disease, and in 36 cases I have removed the appendix even when apparently normal. The procedure is simple, only occupying a few minutes, and it does not appreciably increase the danger of the operation.

If the appendix lies above the brim of the pelvis and is obviously healthy it should not be removed. If, however, the appendix is lying over the brim of the pelvis or dependent in the cavity it should, I believe, be taken away, as in these cases there is a definite risk of subsequent appendicitis or adhesion of the appendix to some part of the pelvis.

If the appendix in the course of any pelvic operation be discovered adherent to an ovary or tube or to a new growth, it is wiser to remove it than merely to separate it from the adhesions.

In view of the importance of the appendix as a cause of pelvic pain and inflammation and as a secondary complication of pelvic disease, the following conclusions appear to be well founded :-

1. The appendix should be examined as a routine precaution in all cases of abdominal section for pelvic disease.

2. The appendix should be removed (a) if it lies at the brim of the pelvis or lies in the pelvis; $(b)$ if it shows any peri-appendical adhesions or contains a concretion; $(c)$ if it is adherent to any pelvic inflammatory swelling or tumour; $(d)$ if it lies in close relation to the pedicle or raw surface left after the removal of any pelvic organ. 


\section{List of Cases in which Adherent Appendix was present as a Complication of Tubo-ovarian Disease.}

\begin{tabular}{|c|c|c|c|c|c|c|}
\hline No. & $\begin{array}{l}\text { Age and Civil } \\
\text { State. }\end{array}$ & Bymptoms. & $\begin{array}{l}\text { Physical } \\
\text { Examinstion. }\end{array}$ & Nature of Operation. & $\begin{array}{l}\text { Condition of } \\
\text { Appendix. }\end{array}$ & Result. \\
\hline 1 & $\begin{array}{l}24 \\
\text { Single. }\end{array}$ & $\begin{array}{l}\text { Recurrent attacks of } \\
\text { abdom, psin with py. } \\
\text { rexis, great loss of } \\
\text { fesh. } \\
\text { Duration } 4 \text { months. }\end{array}$ & $\begin{array}{l}\text { Virgo intacts- } \\
\text { uterus fred by } \\
\text { mass filling rfght } \\
\text { gide of pelvis. }\end{array}$ & $\begin{array}{l}\text { Abdoni. Section. } \\
\text { Numerous omental and in- } \\
\text { tegtinal adhesions. } \\
\text { Both appendages embedded } \\
\text { in perttoneal exudation; } \\
\text { not removed. }\end{array}$ & $\begin{array}{l}\text { Appendix adherent } \\
\text { to floor of pelvis, } \\
\text { purulent appendi- } \\
\text { citis. Removal of } \\
\text { appendix, drain- } \\
\text { age. }\end{array}$ & $\begin{array}{l}\text { Recovery. } \\
\text { Patlentquite well 5 years } \\
\text { after operation. }\end{array}$ \\
\hline 2 & $\begin{array}{c}\mathbf{3 3} \\
\text { Married. } \\
\text { Nopregnancies }\end{array}$ & $\begin{array}{l}\text { Pafn right side of pelvis, } \\
3 \text { years with ocosional } \\
\text { acute attacks and py- } \\
\text { rexfa. } \\
\text { Menorrhagia. }\end{array}$ & $\begin{array}{l}\text { U teras bulky, } \\
\text { fixed, snteflexed } \\
\text { large tubo - ove- } \\
\text { ran mase, right, } \\
\text { reaching floor of } \\
\text { pelvis, cystic. }\end{array}$ & $\begin{array}{l}\text { Carettage } \\
\text { Abdom. Section. } \\
\text { Removal of hydrosalpinx } \\
\text { and hremstoms of right } \\
\text { ovary, very adherent. } \\
\text { Left ovary and tube em- } \\
\text { bedded in adhesions. } \\
\text { Not remored. }\end{array}$ & $\begin{array}{l}\text { Appendix adherent } \\
\text { to anterior surface } \\
\text { of tumour, peri- } \\
\text { appendicitis. }\end{array}$ & $\begin{array}{l}\text { Recovery. } \\
\text { Primary infection was } \\
\text { probably of gonotr. } \\
\text { hoeal origin. }\end{array}$ \\
\hline 3 & $\begin{array}{c}29 \\
\text { Married. } \\
\text { No pregnancy. }\end{array}$ & $\begin{array}{l}\text { Constant right - sided } \\
\text { pelvic pain } 19 \text { months; } \\
\text { menorrhagis. } \\
\text { Left ovary removed } 9 \\
\text { years previously. }\end{array}$ & $\begin{array}{l}\text { Uterus bulky, snte- } \\
\text { flexed, mobile: } \\
\text { right ovary much } \\
\text { enlarged, prolsps- } \\
\text { ed and adherent. }\end{array}$ & $\begin{array}{l}\text { Abdom. Section. } \\
\text { Removal of sclero-cystic } \\
\text { adherent ovary and Fal- } \\
\text { lopian tube. }\end{array}$ & $\begin{array}{l}\text { Appendix in pelvis, } \\
\text { numerous adhe- } \\
\text { gions. }\end{array}$ & $\begin{array}{l}\text { Recorery. } \\
\text { Exudation developed } \\
\text { in the floor of the } \\
\text { pelvis } 14 \text { days after } \\
\text { operation. It was com- } \\
\text { pletely abeorbed in a } \\
\text { month. }\end{array}$ \\
\hline 4 & $\begin{array}{c}\text { C. } 2 . \\
\text { Younger } 12 \\
\text { Jears \&go. }\end{array}$ & $\begin{array}{l}\text { Repested attacks of } \\
\text { pelvic pain for six } \\
\text { yesrs. }\end{array}$ & $\begin{array}{l}\text { Uterus fixed by } \\
\text { perimetric adhe- } \\
\text { sions : adherent } \\
\text { tubo-ovarlan mass } \\
\text { on right side of } \\
\text { floor of pelvis. } \\
\text { Very sensitive. }\end{array}$ & $\begin{array}{l}\text { Abdom. Section. } \\
\text { Uterug covered by fibrin- } \\
\text { ous adhesions. } \\
\text { Right tube and ovary } \\
\text { adherent to floor of pelvis. } \\
\text { Removal. } \\
\text { Left tube and ovary sppar- } \\
\text { ently normal after pepara- } \\
\text { tion of adhesions. }\end{array}$ & $\begin{array}{l}\text { Appendix fred by } \\
\text { adhesions to right } \\
\text { side of pelvis, very } \\
\text { long and tortuous }\end{array}$ & $\begin{array}{l}\text { Recovery. } \\
\text { The patient ins geen } \\
\text { recently; ghe com- } \\
\text { plaing of some pein } \\
\text { in left avary whlch } \\
\text { now enlarged and ten- } \\
\text { der. }\end{array}$ \\
\hline 6 & $\begin{array}{c}32 \\
\text { Married. } \\
\text { No pregnancy. }\end{array}$ & $\begin{array}{l}\text { Recurrent attacks of } \\
\text { pain in right side } \\
\text { of pelvis for two } \\
\text { years. ovsriotomy } \\
\text { performed for left } \\
\text { cystic ovarian tu- } \\
\text { mour } 4 \text { years ago. }\end{array}$ & $\begin{array}{l}\text { Uterus antefiexed, } \\
\text { movable. Tender, } \\
\text { fixed mass in right } \\
\text { broad ligament, } \\
\text { induration pass. } \\
\text { ing anterior to } \\
\text { uterus. }\end{array}$ & $\begin{array}{l}\text { Omentum adherent to blad- } \\
\text { der. } \\
\text { Right Fallopian tube and } \\
\text { ovary much enlarged, } \\
\text { embedded in dense ad- } \\
\text { hesiong to cæcum. } \\
\text { Removal of right appen- } \\
\text { dages. }\end{array}$ & $\begin{array}{l}\text { A p pe ndix retro- } \\
\text { ceecal and adher- } \\
\text { ent, the tip only } \\
\text { lying froe in pel- } \\
\text { ve. } \\
\text { Appen di x con- } \\
\text { tained thick pus. }\end{array}$ & $\begin{array}{l}\text { Recovery. } \\
\text { In this case there was } \\
\text { no evidence of nterine } \\
\text { infection, Hence the } \\
\text { appendlx was probably } \\
\text { the primary cause of } \\
\text { the peritonitls. }\end{array}$ \\
\hline 6 & $\begin{array}{l}\text { M4 } \\
\text { Mears. } \\
\text { C. } 2 .\end{array}$ & $\begin{array}{l}\text { Hypogastric and right } \\
\text { iliac pain since last } \\
\text { confinement } 3 \text { years } \\
\text { ago. Menorrhagia. }\end{array}$ & $\begin{array}{l}\text { Uterus retroflexed, } \\
\text { ond enlarged. } \\
\text { Right ovary pro- } \\
\text { lapsed and cystlc. }\end{array}$ & $\begin{array}{l}\text { Abdom, Section. } \\
\text { Ventri-fration. } \\
\text { Removal of sclero-cystic } \\
\text { right ovary. } \\
\text { No adhesions. }\end{array}$ & $\begin{array}{l}\text { Appendix very long } \\
\text { and tortuous in } \\
\text { pelvis, contsining } \\
\text { a fæcsl concretion. }\end{array}$ & Recovery. \\
\hline 7 & $\begin{array}{c}29 \\
\text { Bingle. }\end{array}$ & $\begin{array}{l}\text { Constsnt right-sided } \\
\text { pain 18 months, eg- } \\
\text { pecially at menstrual } \\
\text { periods. }\end{array}$ & $\begin{array}{l}\text { Uterug anteflexed, } \\
\text { moblle. } \\
\text { Right ovary en- } \\
\text { larged and tender. } \\
\text { Abdomen tender- } \\
\text { ness at McBur- } \\
\text { neg's point. }\end{array}$ & $\begin{array}{c}\text { Abdom. Section. } \\
\text { Removal of sclero-cystic } \\
\text { and enlarged right ovary. }\end{array}$ & $\begin{array}{l}\text { Appendix odherent } \\
\text { fn its whole length } \\
\text { to csecum at brim } \\
\text { of pelvis. }\end{array}$ & $\begin{array}{l}\text { Recovery. } \\
\text { Canse of pain doubtiul. }\end{array}$ \\
\hline 8 & $\begin{array}{l}\text { M2 } \\
\text { M. years. } \\
\text { C. } 1 .\end{array}$ & $\begin{array}{l}\text { Congtant right iliac } \\
\text { pain } 2 \text { jears, with } \\
\text { recurrent attack of } \\
\text { acute inflammation. } \\
\text { Menorrhagia. }\end{array}$ & $\begin{array}{l}\text { Uterus enlarged, } \\
\text { anteflexed, ftred : } \\
\text { tender Bwelling } \\
\text { flls right side of } \\
\text { pelvis. }\end{array}$ & $\begin{array}{l}\text { Curettage. } \\
\text { Abdom. Section. } \\
\text { Cacum sdherent to pos- } \\
\text { terior wall of uterus, } \\
\text { Right appendages lying in } \\
\text { floor of pelvis; hydrosal- } \\
\text { pinx and honstoms of } \\
\text { ovary. } \\
\text { Left tubo-overian cyst. }\end{array}$ & $\begin{array}{l}\text { Appendix adherent } \\
\text { along anterior sur. } \\
\text { face of tubo-ovs. } \\
\text { rian mass, ite top } \\
\text { being close to } \\
\text { uterine cornua. }\end{array}$ & $\begin{array}{l}\text { Recovery. } \\
\text { No evidence of uterine } \\
\text { infection, probably ap- } \\
\text { pendix was primary } \\
\text { gource of the pelvic } \\
\text { peritonitis. }\end{array}$ \\
\hline$\theta$ & $\begin{array}{l}30 \\
\text { Married. } \\
\text { C. } 2 .\end{array}$ & $\begin{array}{l}\text { Extre - uterine geats- } \\
\text { tion, recurrent attacks } \\
\text { of pain, uterine hre- } \\
\text { morrhbge. } \\
\text { Sudden illness, } 1 \text { month }\end{array}$ & $\begin{array}{l}\text { Pelvis flled by } \\
\text { mass pushing ute- } \\
\text { rus forward. }\end{array}$ & $\begin{array}{l}\text { Abdom. Section. } \\
\text { Uterus and sppendages } \\
\text { ombedded in frm blood- } \\
\text { clot. Rupture of left } \\
\text { tube. Fotus 2f inches } \\
\text { long. } \\
\text { Removal of uterus and ap- } \\
\text { pendages. }\end{array}$ & $\begin{array}{l}\text { Appendix adherent } \\
\text { in pelvis to right } \\
\text { tube and ovary. }\end{array}$ & Recovery. \\
\hline 10 & $\begin{array}{c}31 \\
\text { Married. } \\
\text { No pregnancy. }\end{array}$ & $\begin{array}{l}\text { Extrs - uterine gesta. } \\
\text { tion. } \\
\text { Right iliac poin, sudden } \\
\text { illness } 6 \text { months pre- } \\
\text { viously. }\end{array}$ & $\begin{array}{l}\text { U ter a mobile; } \\
\text { fled. tender mass } \\
\text { flling up right } \\
\text { broad ligament. }\end{array}$ & $\begin{array}{l}\text { Abdom. Section. } \\
\text { Right bæmatosalpinx with } \\
\text { numerous adhesions. }\end{array}$ & $\begin{array}{l}\text { A ppendi x thick. } \\
\text { ened and torta. } \\
\text { ous, adherent to } \\
\text { outer end of Fal. } \\
\text { lopian tube. }\end{array}$ & Recovery. \\
\hline
\end{tabular}


Rufrerences.

1. Hawkins (H. P.). "Diseases of the Vermiform Appendix," London, 1895.

2. Robinson. New York Medical Record, vol. xlviii., 1895.

3. Lockwood. "Appendicitis, its Pathology and Surgery."

4. Kelly. "Diseases of the Vermiform Appendix," 1905.

5. Clado. Mém. de la Société de Biologie, Paris, 1892.

6. Durand. Progrès Médical, 1895.

7. Craig. Journal Amer. Medical Association, 1904, p. 1438.

8. Poirier. "The Lymphatics," translated by C. Leaf, p. 194.

9. Krönig und Döderlein. Operative Gynäkologie, 1905, p. 346.

10. Hermes. Zeitschrift für Chirurgie, 1898.

11. Clark (J. G.). Amer. Journal of Obstetrics, 1904, No. 5.

12. Peterson. Trans. Amer. Gynecol. Society, 1904, p. 351.

13. Robb (H.). Trans. Amer. Gynecol. Society, 1905.

14. Ribbert. Virchow's Archiv für path. Anat., 1893, Bd. 132.

15. Treves (Sir F.). Med. Chirurg. Trans. (London), 1905.

16. Rotter. Deutsch. med. Wochenschr., 1900, No. 40.

17. Bland-Sutton. Brit. Med. Journal, Feb., 1905.

18. MacLaren. Amer. Gyn. and Obstet. Journal, 1900, vol. xvii., p. 14.

19. Lea. "A Note on Vaginal Drainage in Children and Young Adults," Medical Chronicle (Manchester), May, 1906.

20. Smith (Lapthorn). Montreal Med. Journal, March, 1906. 